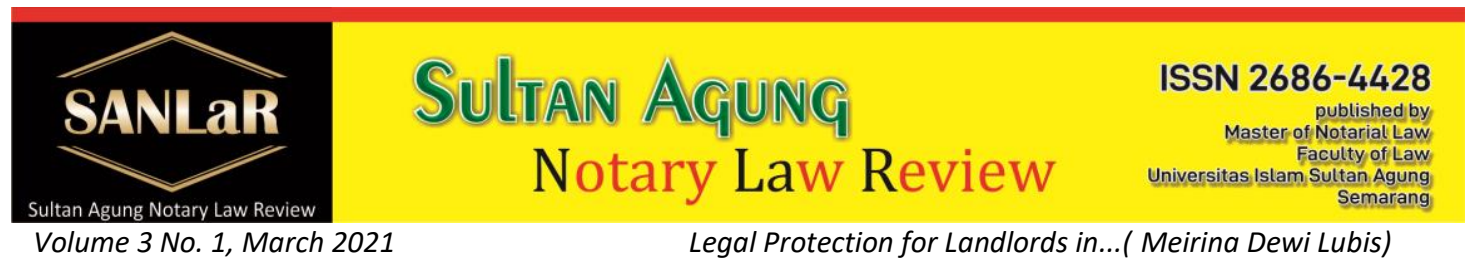

\title{
Legal Protection for Landlords in Housing Development Cooperation Agreement in Kendari City
}

\author{
Meirina Dewi Lubis ${ }^{*}$
}

*) Students of Master of Notary Law, Faculty of Law, Universitas Islam Sultan Agung (UNISSULA) Semarang, E-mail:

\begin{abstract}
The purpose of the research in this study is to know and analyze the legal protection for landowners in the housing development cooperation agreement in Kendari City. Based on the results of research shows that the legal protection of the fulfillment of the rights of parties, especially landowners if one party makes a performance or breach of promise in a housing development agreement depends on the strength of the housing development agreement made, that is, if made by deed under hand its protection is in accordance with the protection of the Act under hand. Whereas when made by or in the presence of a Notary then by itself the act becomes a Notary deed so that its protective force is in accordance with the protection of the Authentic Act.
\end{abstract}

Keywords: Legal Protection; Land Owners; Cooperation Agreements; Housing Development.

\section{Introduction}

The increase in economic growth that occurs as a result of the rate of development, increases the need for land for the benefit of industry, services and settlements such as housing and offices. Human needs for land are increasing due to development activities and growing population growth that is not offset by limited land provision. That imbalance has raised questions in many ways. With the growing human need for land, the land problem is not only a juridical problem, but also an economic, social and political problem. This is because land is a very basic need and occupies a very important and strategic position in life and development, now and in the future. ${ }^{1}$

Soil is a stationary object / fixed object due to its nature. Land cannot be moved. What can be transferred or transferred are the rights to a piece of land. The transfer or transfer of rights to this land must be proved by an authentic act. ${ }^{2}$

Land is an immovable object whose economic value increases over time. This is because the land has many benefits for human life, such as for example used as agricultural land, livestock, residential land / residence, place of business

\footnotetext{
${ }^{1}$ Florianus SP. Sangsun.(2007).Tata Cara Mengurus Sertipikat Tanah. Visimedia. Jakarta. p. 2

${ }^{2}$ Op.Cit. page 22.
} 
(business) and others. Not a single sector of human life can escape the ground. Due to the many benefits of land for human life, and its availability over time is increasingly limited, the value of land is getting higher and higher in human life in society. ${ }^{3}$

The owners of land / land that is large enough at the present time is also quite limited in number. Moreover, the land area is sufficient to build a housing complex (real estate) in large quantities, then the land is generally in demand by developers (developers), both individuals and groups to buy in cash to landowners or carry out the construction of houses on the land. by entering into a housing cooperation agreement between the landowner (both individually and collectively) with the developer (developer) both individually and in groups. ${ }^{4}$

The housing business done through the construction and distribution of houses is very much found today, but there are still many people who do not know about the construction and distribution of houses. Housing is one of the basic human needs both as a place to live and as a place of business. However, not all communities can enjoy and own a decent, healthy, safe and compatible home, especially in densely populated urban areas.

The concept of the business of construction and division of houses, hereinafter referred to as the term building agreement in the field of housing, is considered beneficial for both parties to the agreement. Djaren Saragih gives the meaning and function of the revenue sharing agreement or also called Deelbouw Overeenkomst which is the legal relationship between a person entitled to land with another party (second), where the second party is allowed to cultivate the land in question, the result of land processing is divided two between those who are entitled to the land and those who cultivate the land. ${ }^{5}$

Humans are social beings. This view of Aristotle gives us an understanding of how a relationship is built between one person and another. ${ }^{6}$ When the relationship is built, there are many agreements, which at a higher level turn into an agreement. In general, in everyday life, people make covenants, both written and oral. Civil law is a way of regulating those bonds, regarding the rights and interests of individuals in society. The tradition of mainland Europeans tying themselves in civil law then introduced us to the division of law, into public law and private law or often referred to as civil law. While in the Anglo-Saxon system (common law) this division is not known. It is the history of Dutch civil law that at the time was considered the most perfect law,

If we refer to the provisions of Article 1313 of the Civil Code, an Agreement is an act of one or more persons who bind themselves to another person. , onrechmatige daad. To make it easier for everyone to have the same understanding as the standard in making an alliance or agreement, it is regulated

\footnotetext{
3 J.Satro (2006). Hukum Perjanjian. Citra Aditya Bakti. Bandung. p.37.

${ }^{4}$ R.Subekti. (2005). Hukum Perjanjian. Armico. Bandung. p. 14.

${ }^{5}$ Djaren Saragih. (1984). Hukum Adat Indonesia. Tersito.Bandung. p. 97.

${ }^{6}$ https://plato.stanford.edu/entries/aristo tle / Accessed August 15, 2020
} 
in terms of the legality of an agreement in Article 1320 of the Civil Code. That, "A new contract or agreement is said to be valid if it is in the form of a consensus, the competence of the parties, on certain matters and a reason (causa) that is halal."

So an agreement made by the developer becomes valid and binding legally, between the developer and the landowner if they meet those conditions. If not, then the agreement is void for the sake of the law. "

The agreement that is the object of study is a housing development cooperation agreement made by the landowner with the developer. In Article 1233 of the Civil Code, it is stated that the alliance was born for two reasons, first because of the consent of the parties, and second, because of the law. A housing development cooperation agreement can occur if the landowner and the developer agree to enter into an agreement, while the agreement contains that the landowner gives permission to the developer to manage the land by building several units of shop houses and the shop house is the object of agreement to be shared by the parties agree to the agreement. Every agreement embraces the basics of contractual freedom, which provides for the freedom to enter into and determine agreements that do not conflict with the law of decency and public order. Article 1338 paragraph (3) of the Civil Code which states that the agreement must be carried out in good faith. ${ }^{7}$ An agreement is made for those who contain the rights and obligations of the parties is an act made in the presence of a notary who is authentic. Notary is a public official given by law with the authority to make all agreements and acts and required by interested parties. ${ }^{8}$ Civil Code in the third book also regulates the legal relationships between people and people (individual rights), although it may be the object as well as an object. ${ }^{9}$ Legal relationships between one party and another cannot arise on their own. The relationship is created by the existence of "legal action" / rechtshandeling. ${ }^{10}$

Housing development cooperation agreement shall not be contrary to the rules of law, decency and public order, and must meet the conditions of the validity of the agreement set out in Article 1320 of the Civil Code. Agreements can arise if landowners and developers agree to enter into an agreement. In the agreement it is stated that the landowner gives permission to the developer to build several units of shops, housing and houses on his land and then become the object of the agreement to be shared by both parties in accordance with the agreement. In the wake-up agreement, there is generally an agreement made before the Notary with an authentic act. In principle,

\footnotetext{
${ }^{7}$ Mariam Darus Badrulzaman.(2001). Kompilasi Hukum Perikatan. Citra Aditya Bakti.Bandung. p. 83

${ }^{8}$ Suhrawadi. (1994). Etika Profesi Hukum. SInar Grafika.Jakarta. p.59

${ }^{9}$ R. Subekti. (1982). Pokok-Pokok Hukum Perdata. PT. Intermasa. Bandung. p. 123.

${ }^{10}$ M. Yahya Harahap. (1986). Segi-Segi Hukum Perjanjian. Alumni. Bandung. p. 7
} 
According to Article 1458 of the Civil Code at the time the housing development cooperation agreement is made, the sale and purchase between the developer and the landowner has taken place even though the price has not been paid. The agreement made by the developer and the landowner, in fact so that the principle of balance / proportionality is fulfilled. In practice, the agreement is built to not provide legal protection and certainty, so that it can be detrimental to one party, namely the landowners who are in a weak position. ${ }^{11}$

In practice the building agreement for landowners and developers, both individuals and groups, begins with the making of an act

cooperation agreement made by a notary with an authentic act. In the clause of the cooperation agreement made by a notary using the authentic act, there are generally some criteria promised between the landowner and the developer contained in the cooperation agreement, among others:

a. Landowners obtain a number of house units with type, land area, building area and building materials that have been agreed upon between the landowner and the developer without the addition of money from the developer to the landlord.

b. Landowners obtain a number of housing units with type, land area, building area and building materials that have been agreed upon between the landowner and the developer, with the addition of a sum of money given by the developer to the landlord. ${ }^{12}$

Basically, the agreement arose to remain anonymous in the Civil Code. Agreements are born for the birth and development of the needs of the people who want them, due to the rapidly evolving demands of business law in today's society. An anonymous / unnamed agreement in book III of the Civil Code of Civil Procedure is called an anonymous agreement or an innominaat agreement or an onbenoemde agreement. However, although the agreement arose to be unknown in book III of the Civil Code of Law concerning the law of the agreement, but its provisions are still subject to the book III of the Civil Code, especially on the general principles of the agreement. ${ }^{13}$

Implementation of housing development carried out by the developer who is also an investor (investor) on land owned by landowners through a housing development cooperation agreement between the developer and the landowner, made by a notary through an authentic act that entitles and the obligations between the developer and the landowner as well as the rights and obligations between the developer and the landowner, then this research will discuss further on how legal protection for landowners in a housing development cooperation agreement made before a notary in Kendari City, when there are

\footnotetext{
${ }^{11}$ Agus Yudha Hernoko.(2002). Hukum Perjanjian Asas Proporsional Dalam Perjanjian Komersial. Laksbang Mediatama. Yogyakarta. p. 27

12 Mariam Darus Badrullzaman.(2005). Hukum Perjanjian Bisnis. Citra Aditya Bakti. Bandung. p. 109.

${ }^{13}$ Gunawan Wijaya (2007). Seri Hukum Bisnis Memahami Prinsip Keterbukaan(Aan vulend Recht) dalam Hukum Perdata. Raja Grafindo Persada. Jakarta. p. 25
} 
problems in its implementation.In addition, this research will also discuss how the notary is responsible in the event of a dispute / dispute between the parties, namely the developer and the landowner.

\section{Research Methods}

The method used in this writing is empirical juridical. Juridical approach (law is seen as the norm or das sollen), because in discussing the problems of this research using legal materials (both written and unwritten law or both primary and secondary legal material). Empirical approach (law as a social, cultural or das sein reality), because in this study primary data obtained from the field are used.

\section{Results and Discussion}

Legal Protection for Landlords in Housing Development Cooperation Agreement in Kendari

An agreement is an event in which a person promises to another person or where the two people promise each other to do something, from this event, a relationship arises between the two people called an alliance. ${ }^{14}$ Based on Article 1320 of the Civil Code, the legal conditions for the agreement are:

a. Those who bound him agreed

b. Skills To Make An Agreement

c. A Certain Thing

d. A Halal Reason

Pregulations on housing development can be found in Act No. 1 of 2011 on Housing and Residential Areas. Under the Act, housing is a collection of houses as part of a settlement, both urban and rural, which is equipped with infrastructure, facilities, and public utilities as a result of efforts to fulfill a habitable home. While the house is a building that serves as a decent place to live, a means of family building, a reflection of the dignity and dignity of its occupants, as well as assets for the owner. The object of the agreement itself the developer with the landowner has determined independently, as well as the housing development agreement, as long as it does not conflict with or in accordance with the provisions of law, decency and public order. In Article 1338 paragraph 3 of the Civil Code Book, it also states that every agreement must be carried out in good faith. Thus, it can be said that housing development agreements are generally related to landowners and developers in general practice so as to be guided by the basic provisions of contractual freedom in Article 1338 paragraph (1) and Article 1320 of the Civil Code.

Conflict in the housing development agreement is something that does not cover the possibility of problems and problems caused by it, such as performance or

\footnotetext{
${ }^{14}$ Subekti. (1987). Hukum Perjanjian. Intermasa.Jakarta. p. 1.
} 
breach of promise can also occur due to accident, negligence and without error. As for Wanprestasi or breaking promises or not fulfilling the alliance there are four kinds, namely:

a. Do not do what you are supposed to do to make an alliance

b. Execute what is promised, but not as promised

c. Do what is promised but it is too late

d. Doing something that according to the agreement he can not do. ${ }^{15}$

As a result of breach of promise / Wanprestasi in the housing development agreement which of course brings losses to the parties themselves, especially to the landowners. The legal position of landowners and developers and in this research, in the implementation of housing development agreements, is one of the consensual agreements (reciprocity) then that is the obligation of landowners that is the right of the developer owner or development implementer. On the other hand, what is the obligation of the capital owner or developer is the right of the landowner. Legal protection of landowners with developers who enter into housing development agreements can basically be avoided by taking precautions through agreements reached by both parties, compensation, and cancellation of the agreement. ${ }^{16} \mathrm{By}$ making an agreement before the Notary between the landowner and the housing development developer can protect the landowners from fraud that may occur during the construction of the housing.

Article 15 paragraph (1) of the UUJN, that the Notary is authorized to make an authentic act on all acts, agreements, and stipulations required by law and / or required by stakeholders to be stated in the authentic act, guaranteeing the date of enactment, keeping deeds, giving grosse, copies and quotations of the act, during the making of the act is done and not also assigned or exempted to other officials or other persons prescribed by law. In the agreement they agreed upon. Therefore, there is a need for legal protection for the parties to be able to provide legal certainty and maintain the fulfillment of the interests and rights of each party. Legal protection against the fulfillment of the rights of parties, especially landowners if one of the parties makes a promise or breach of promise in the housing development agreement depends on the strength of the housing development agreement made, that is, if made by deed under hand then its protection is in accordance with the Act under hand. Whereas when made by or in the presence of a Notary then by itself the act becomes a Notary deed so that the strength of its protection is in accordance with the protection of the Authentic Act.

\footnotetext{
${ }^{15}$ Ahmadi Miru. Sakka Pati. (2008). Hukum Perikatan. Rajawali Pers. Jakarta. p. 12 https://www.hukumonline.com/klinik/detail/ulasan/lt50a05)923cb397/dasar-hukum-bagi developer-untuk-fasilitas-umum/
} 


\section{Closing}

\subsection{Conclusion}

Based on the results of the research can be drawn the following conclusions:

Legal protection for landowners in the housing development cooperation agreement in the city of Kendari that is, in the event of a dispute between the landowner and the developer, the landowner can file a legal effort based on the agreement that has been made before the Notary. The agreement made before the Notary is an authentic proof, which has a strong evidence

\subsection{Suggestions}

The suggestions that the author can make from this writing are as follows:

It is recommended for the community, especially landowners in entering into agreements with housing development developers to be able to make authentic agreements between landowners and developers to avoid any disputes later in the day.

\section{References}

Books:

[1] Agus Yudha Hernoko. (2002). Hukum Perjanjian Asas Proporsional Dalam Perjanjian Komersial, Laksbang Mediatama, Yogyakarta.

[2] Ahmadi Miru, Sakka Pati. (2008). Hukum Perikatan, Rajawali Pers, Jakarta.

[3] Djaren Saragih. (1984). Hukum Adat Indonesia, Tersito, Bandung.

[4] Florianus SP. Sangsun. (2007). Tata Cara Mengurus Sertipikat Tanah, Visimedia, Jakarta.

[5] Gunawan Wijaya. (2007). Seri Hukum Bisnis Memahami Prinsip Keterbukaan (Aan vulend Recht) dalam Hukum Perdata, Raja Grafindo Persada, Jakarta.

[6] J.Satro. (2006). Hukum Perjanjian, Citra Aditya Bakti, Bandung. 
[7] M. Yahya Harahap. (1986). Segi-Segi Hukum Perjanjian, Alumni, Bandung.

[8] Mariam Darus Badrullzaman. (2005). Hukum Perjanjian Bisnis, Citra Aditya Bakti, Bandung.

[9] Mariam Darus Badrulzaman. (2001). Kompilasi Hukum Perikatan, Citra Aditya Bakti, Bandung.

[10] R. Subekti. (1982). Pokok-Pokok Hukum Perdata, PT. Intermasa, Bandung.

[11] R.Subekti. (2005). Hukum Perjanjian, Armico, Bandung.

[12] Subekti. (1987). Hukum Perjanjian, Intermasa, Jakarta.

[13] Suhrawadi. (1994). Etika Profesi Hukum, SInar Grafika, Jakarta. 